\title{
Evaluating User Satisfaction Towards E-learning Platform During COVID-19 Crisis
}

Khairilmizal Samsudin, Nurulilyana Sansuddin, Mohamad Fahmi Hussin, Nur Emileen Abd Rashid, Ainul Husna Kamarudin, Nor Ayu Zakaria, Nur Eizati Mohd Ali, Nur Fatin Najihah Ghazali and Nur Hannani Abdul Ghani

To Link this Article: http://dx.doi.org/10.6007/IJARBSS/v11-i12/11976 DOI:10.6007/IJARBSS/v11-i12/11976

Received: 17 October 2021, Revised: 20 November 2021, Accepted: 01 December 2021

Published Online: 26 December 2021

In-Text Citation: (Samsudin et al., 2021)

To Cite this Article: Samsudin, K., Sansuddin, N., Hussin, M. F., Rashid, N. E. A., Kamarudin, A. H., Zakaria, N. A., Ali, N. E. M., Ghazali, N. F. N., \& Ghani, N. H. A. (2021). Evaluating User Satisfaction Towards E-learning Platform During COVID-19 Crisis. International Journal of Academic Research in Business and Social Sciences, 11(12), 2471-2481.

Copyright: (C) 2021 The Author(s)

Published by Human Resource Management Academic Research Society (www.hrmars.com) This article is published under the Creative Commons Attribution (CC BY 4.0) license. Anyone may reproduce, distribute, translate and create derivative works of this article (for both commercial and non0-commercial purposes), subject to full attribution to the original publication and authors. The full terms of this license may be seen at: http://creativecommons.org/licences/by/4.0/legalcode

Vol. 11, No. 12, 2021, Pg. 2471- 2481

Full Terms \& Conditions of access and use can be found at http://hrmars.com/index.php/pages/detail/publication-ethics 


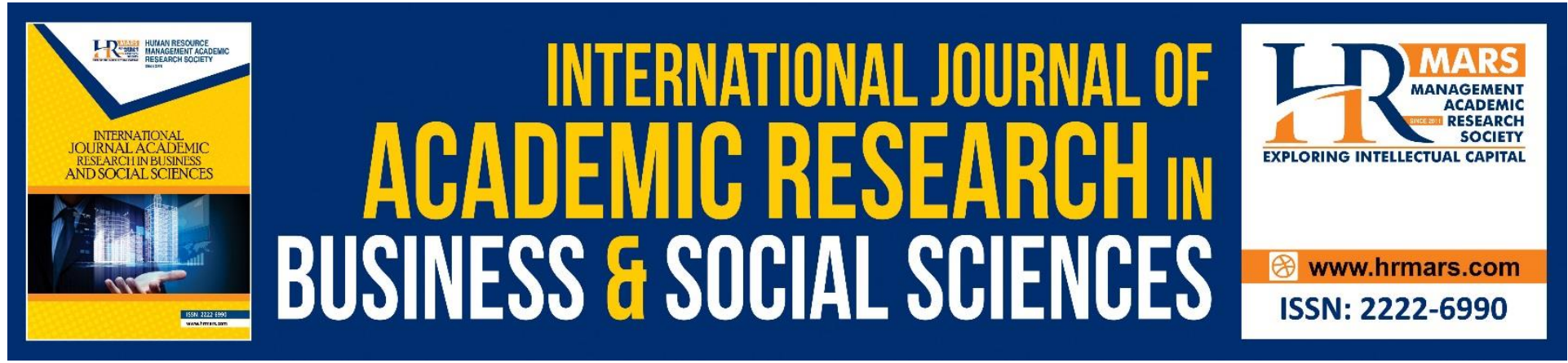

\title{
Evaluating User Satisfaction Towards E-learning Platform During COVID-19 Crisis
}

\author{
Khairilmizal Samsudin and Nurulilyana Sansuddin \\ Universiti Sains Malaysia, Malaysia \\ Mohamad Fahmi Hussin \\ UiTM, Malaysia \\ Nur Emileen Abd Rashid \\ Universiti Teknologi MARA, Malaysia \\ Ainul Husna Kamarudin \\ Institute of Medical Science Technology (UniKL-MESTECH), Malaysia
}

Nor Ayu Zakaria

University of Technology MARA \& UiTM, Malaysia

\author{
Nur Eizati Mohd Ali \\ Consist College, Malaysia
}

\section{Nur Fatin Najihah Ghazali and Nur Hannani Abdul Ghani Universiti Sains Malaysia, Malaysia}

\begin{abstract}
The outbreak of the COVID-19 epidemic has spread worldwide causing Movement control order in Malaysia since mid-March 2020 however, the teaching and learning process in university still needs to proceed as usual. Hence universities improvised their teaching and learning process to fully online via an online platform. This study concentrates on student satisfaction as an end-user towards E-learning hence, the objective of this paper is to assess the acceptance of students; to evaluate the overall satisfaction; to identify challenges, and finally; to proposed improvements towards the implementation of the teaching and learning process through E-learning. Based on the standards population sampling of $95 \%$ confidence level with a $5 \%$ margin of error, the respondent has answers sets of five (5) section predeveloped questionnaires aiming at measuring end-user satisfaction towards E-learning platform. Results show that the information quality, system usefulness, system usage characteristics of E-learning is highly acceptable with overall satisfaction mean of 3.7 and SD
\end{abstract}


of 0.8, although lecturer capacity and effort in centralizing teaching and learning process and system improvement for E-learning need to be improved. Hence, the authors are in the opinion that the teaching and learning process through E-learning can be drastically improved.

Keywords: COVID-19, E-Learning, User Satisfaction, Student Learning

\section{Introduction}

The outbreak of the COVID-19 epidemic has spread worldwide with more than 1.5 million reported cases involving 100,000 deaths as of April 12, 2020 (WHO, 2020). The epidemic has been discovered for the first time in late 2019 in China. Specifically, the World Health Organization has published a chronology of the outbreak found from December 31, 2020, in Wuhan City, Hubei Province in China to the discovery of cases of unknown etiological pneumonia (WHO, 2020). In the short term (2020), a total of 44 patients with unknown etiological pneumonia were reported to WHO by the Chinese authorities. Following the outbreak, it is believed to have spread to Asian countries where the first case was found in Thailand on January 8,2020 . Hence, the outbreak was declared as a world health emergency by WHO on January 31, 2020 (WHO, 2020).

Meanwhile in Malaysia, the country Ministry of Health (MOH) has confirmed that the first case of COVID-19 involved three China citizens entering Malaysia via Johor from Singapore on January 23, 2020 (Harian, 2020). Since then, the number of COVID-19 cases in Malaysia has increased, however, as of April 12, 2020, through the effort shown by $\mathrm{MOH}$ the death rate in the country is significantly low $(0.016 \%)$ comparing to the international percentage of $6.13 \%(\mathrm{MOH}, 2020 ; \mathrm{WHO}, 2020)$. The percentage was materialized due to the effort by the government of Malaysia through the implementation of the Movement Control Order (MCO) in stages since March 18, 2020 (Muhyiddin, 2020). Up till April 12, 2020, the MCO has officially planned its implementation for six consecutive weeks till April 28, 2020.

Taking a proactive effort, as part of 16 initiatives to ensure the well-being and safety of all University Science Malaysia (USM) members, USM has directed that all teaching and learning process to be conducted online starting March 15, 2020, in an effort to curb the transmission of the COVID-19 virus that has been declared a pandemic by the World Health Organization (WHO) as part of (Faisal Rafiq, 2020). Supporting these initiatives, through its group of available experts, USM has devised a strategic plan entitled 'Response and Readiness Plan for COVID-19 Pandemic and Other Infectious Diseases Outbreaks' in providing guidelines on the readiness, response, and communication needed to address the COVID-19 pandemic and other infectious diseases related to public health emergency issues in the context of USM. The comprehensive framework is aimed at minimizing the impact of COVID-19 on the social and health well-being of students and staff, with emphasis on the public health aspects of USM and the community as a whole which include smooth teaching and learning process (Taskforce USM COVID-19 Pandemic, 2020).

Due to the COVID-19 crisis and the MCO enforced by the government, the education sectors in Malaysia has undergone drastic changes in which teaching and learning process need to evolve from full face-to-face or mixed-mode teaching to $100 \%$ fully online teaching and learning process. USM is one of the universities that has taken this proactive approach to drastically change their teaching and learning process during COVID-19. Online teaching and learning have been introduced in USM since 2016. However, it is not widely practiced as USM only implements mixed-mode teaching. eLearn@USM is the official E-learning portal for USM lecturers and students which is deployed using Moodle as a Learning Management System 
(USM, 2020). All courses offered by USM can be found in the portal. The eLearn@USM enables smooth course administration, delivery, and management between lecturers, students, and course administrators.

Initially, USM implements full face-to-face or mixed-mode teaching and learning processes only, hence for lecturers and students to fully utilize eLearn@USM platforms, several key challenges may need to be addressed. Among others is the preparedness of the lecturer to upload material and conduct activity using eLearn@USM, the student preparedness towards the full implementation of eLearn@USM and the preparedness of eLearn@USM platforms to cater the teaching and learning process from both lecturer and students. This study concentrates on student satisfaction as an end-user towards eLearn@USM platforms in terms of information quality, system usefulness, system usage characteristics and overall satisfaction (Armstrong et al., 2005). Through this key item, researchers believed that the teaching and learning process through eLearn@USM can be significantly improved. Hence it is the objectives of this study to assess the acceptance of students based on information quality, system usefulness, and system usage characteristics; to evaluate the overall satisfaction; to identify challenges, and finally; to proposed improvements towards the implementation of teaching and learning process through eLearn@USM especially during crisis situations which require 100\% implementation of teaching and learning process online..

\section{Method}

For the purpose of this paper, eLearn@USM is validated by using validity tools that refer to the degree in the study tool that is truly measuring what it is intended to measure in achieving study success (Hussin et al., 2012; Khairilmizal et al., 2019). There are two (2) types of validity namely the content validity and face validity method where this paper recognizes the use of face validity methods to measure success in implementing the system towards enduser (Armstrong et al., 2005; Khairilmizal, Hussin, Husna, et al., 2017).

The developed system went through a face validity process by eLearn@USM end user. The selected user is 125 first to fourth-year students undergoing a degree in Environmental and Occupational Health at School of Health Science, Universiti Sains Malaysia. Based on the standards population sampling of $95 \%$ confidence level with a $5 \%$ margin of error (Leveugle et al., 2009), it is calculated that a total number of 95 respondents are needed. this study recorded a total of 104 respondents.

As all teaching and learning activities are conducted through eLearn@USM during the MCO by the Malaysian government, students were asked to evaluate the eLearn@USM using a structured questionnaire (Fig 1). The questionnaire which is adopted from (Armstrong et al., 2005; Khairilmizal, Hussin, Yassin, et al., 2017) containing views on the developed system towards domain experts and end-user. Specifically, for the purposes of the eLearn@USM, students are the end-users. However, respondent names will not be divulged in this paper in accordance with respondent privacy and confidentiality (Johnston, 2015; Kaiser, 2009).

The challenges in collecting the response from the respondent are that all respondent is at the different geographical area since the MCO started hence, to achieve wide geographical area (Roosli, 2010) of data, respondent was engaged in online questionnaires. (Guin, 2012) Stated that online questionnaires reduce the burden of respondents such as questionnaire length, topic salience, cognitive burden and frequency of questionnaire requests, which will increase the accuracy of the collected data. A private group message containing a brief introduction and questionnaire link was sent to all respondents. The 
respondent only has to use the provided link to answer the questionnaire, and upon finish, the response will be automatically recorded.

The questionnaire was developed using Google Forms. As Google Forms provide the ability to provide users with multiple question type (open-ended, close-ended and Likert), record, compile the respondent data and provide basic descriptive statistics (frequency and percentages), Google Forms was used in this study. The use of Google forms also was recognized by other types of research as a questionnaire tool (Sorensen \& Dahl, 2008; Travis, 2010).

Aside from the basic sociodemographic background, the questionnaire consists of four (4) main sections that measure the eLearn@USM through Information quality, system usefulness, system usage characteristics and overall satisfaction of the system.

1. Information quality: to validate information provided by the eLearn@USM and the relevance of the information to the overall end-users information needs;

2. System usefulness: to gain efficiency and effectiveness resulting from eLearn@USM usage;

3. System usage characteristics: to describes the ease of system use, depth of learning required, and the adaptability of the system to specific requirements of end-users; and

4. Overall satisfaction: to look at overall end-user satisfaction towards the eLearn@USM.

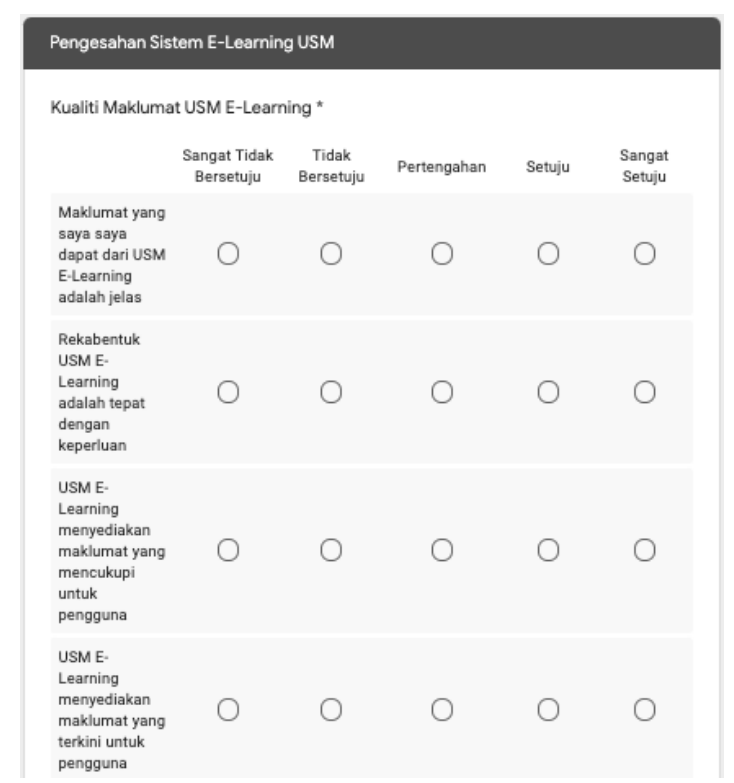

Fig 1: End User Validity Questionnaire for eLearn@USM

Each of the mentioned sections contains sets of questions needed to be answered by the respondent. Each answer will have their scores which will be averaged for each main section. Average marks were calculated and analyzed in order to obtain the end-user views. Average Mean will be calculated in order to have a value that lies within a range of values indicating middle positions and the standard deviation is a parameter that indicates the way in which a probability function or a probability density function is cantered around its mean (Merriam-Webster.com, 2018). Hence, the standard deviation will indicate the reliability of the collected data. Marks were calculated from a Likert scale ranging from 1 - Strongly Disagree; 2 - Disagree; 3 - Moderate; 4 -Agree, and; 5 - Strongly Agree.

Several limitations were identified during this study and the researchers believed that the limitation shall not affect the results of this study. The first limitation is the student 
familiarity towards the eLearn@USM. This is believed to be less significant as all student has been exposed to eLearn@USM since their enrolment into the university and has been using it since. Hence, the first limitation can be neglected.

The second limitations are the accuracy of the recorded information based on the ability of the respondent to answer the questionnaire honestly (Annamalai et al., 2014). However, through an online questionnaire, the identity of the respondents are not recorded, giving the student more freedom in answering the questionnaire. Additionally,(Guin, 2012) also, acknowledges the use of online questionnaires where it is found that an online questionnaire provides significant results and low rates of failure (less than 20\%). Hence the second limitations are also neglected.

\section{Results and Discussion}

The COVID-19 pandemic crisis and MCO in Malaysia have forced the implementation of full $100 \%$ teaching and learning process online. In evaluating student satisfaction as an enduser towards eLearn@USM platforms in terms of information quality, system usefulness, system usage characteristics and overall satisfaction (Armstrong et al., 2005), 104 respondent has answered a set of questionnaire towards eLearn@USM. From the total number of 104 respondents, the distribution of the respondent year of study is $23 \%$ for the first year, $28 \%$ for the second and third year and finally 23\% for the fourth year as illustrated in Fig 2.

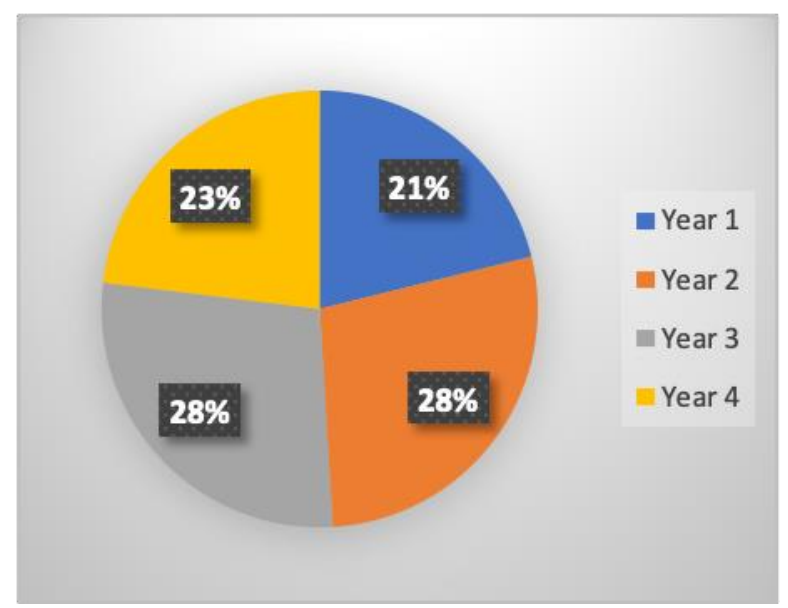

Fig 2: Distribution of respondent year of study

In determining the user satisfaction towards eLearn@USM, respondent was required to give their opinion in terms of system sections, namely information quality, System usefulness, system usage characteristics, and overall satisfaction. Table 1 indicates the mean score and the standard deviation of each system section.

Table 1: Each Sections Mean and Sd for eLearn@USM

\begin{tabular}{|l|l|l|}
\hline Section & Mean Score & SD \\
\hline Information quality & 3.9 & 0.7 \\
\hline System usefulness & 3.8 & 0.8 \\
\hline System usage characteristics & 4.0 & 0.7 \\
\hline Overall satisfaction & 3.7 & 0.8 \\
\hline
\end{tabular}


It can be summarized that eLearn@USM information quality, System usefulness, system usage characteristics, and overall satisfaction are acceptable by the respondent with a mean score between 3.7 to 4.0 out of 5. Adding up, the answers from each respondent also are close to the average with a standard deviation between 0.7 and 0.8 , which indicates the precision of the data (Laal et al., 2017). This low standard deviation indicates that the data points tend to be very close to the mean value which validate the results.

\section{Information Quality}

The first section in evaluating user satisfaction towards eLearn@USM is information quality. The section measures the respondent satisfaction through the information provided, design accuracy, the sufficiency of information, up-to-date information and expectation of user towards provided information.

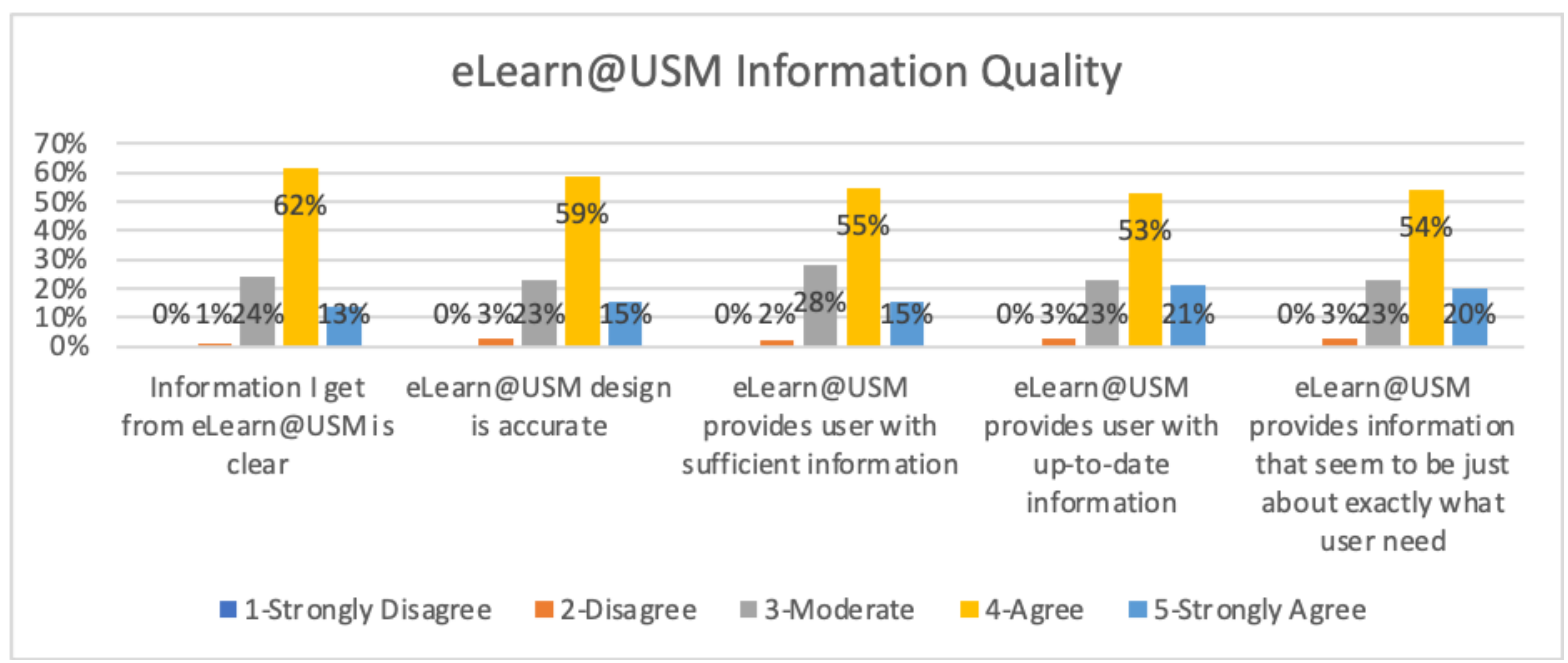

Fig 3: eLearn@USM Information Quality

Fig 3 indicates the percentage of each element in the information quality of eLearn@USM. It can be summarized that the majority of the respondent (above 70\%) agree and strongly agree with the eLearn@USM information quality. Some of the respondents who answer moderate and disagree with eLearn@USM information quality stated that the answer is due to the quality of materials uploaded by the lecturer and clear instructions towards students on lecturer expectations.

\section{System Usefulness}

The second section in evaluating user satisfaction towards eLearn@USM is system usefulness. The section measures the respondent satisfaction through productivity, time-saving and satisfaction towards the teaching and learning process. 


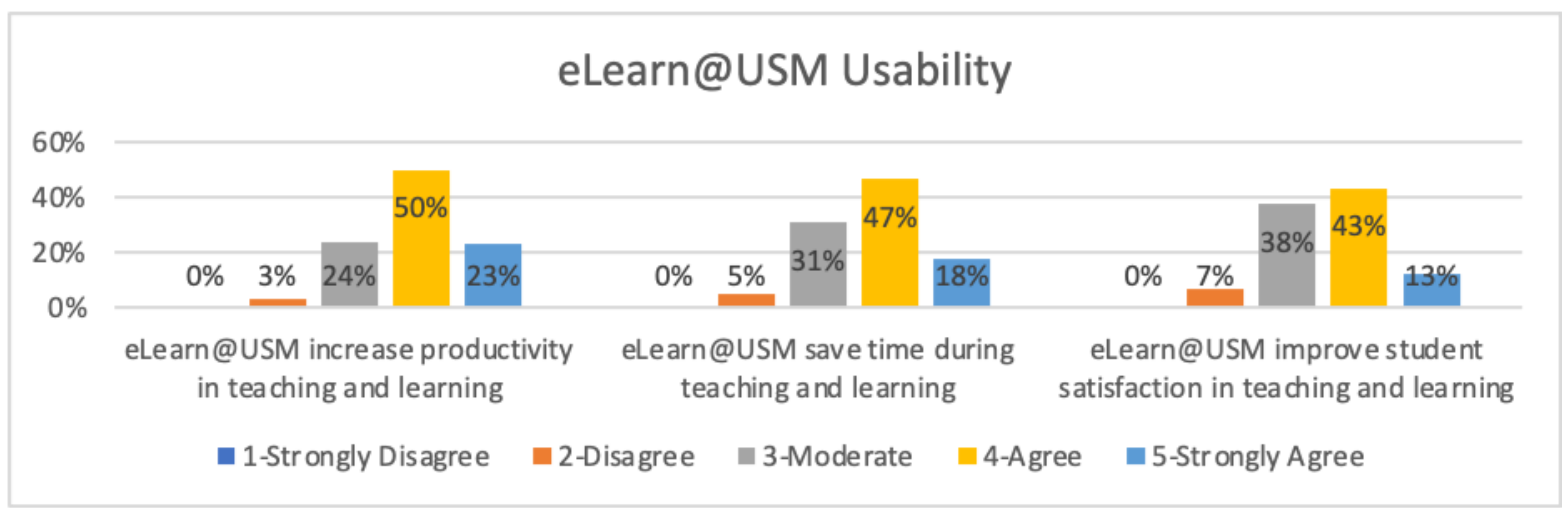

Fig 4: eLearn@USM Usability

Fig 4 indicates the percentage of each element in eLearn@USM usefulness. It is found that more $73 \%$ of respondents agree and strongly agree with eLearn@USM usability to increase productivity towards the teaching and learning process. However, respondents are found to have mixed opinions on eLearn@USM capability to provide time-saving and satisfaction towards the teaching and learning process. Only 65\% respondent to agree and strongly agree on the eLearn@USM usability provide time-saving towards teaching and learning. Some of the respondents stated the reason to be that, many lecturers still using other platforms aside from eLearn@USM for their teaching and learning process causing a non-centralized source of teaching and learning materials. This is supported by the respondent's opinion where only $56 \%$ of respondents agree and strongly agree on eLearn@USM usability satisfaction towards the teaching and learning process. Aside from the non-centralized source of teaching and learning materials, respondents also informed that eLearn@USM usability satisfaction can be improved if it has the capability of notifying the user of any new materials or activity uploaded by their respective lecturer.

\section{Usage Characteristic}

The third section in evaluating user satisfaction towards eLearn@USM is usage characteristics. The section measures the respondent satisfaction through the ease of use, user-friendliness and navigational of eLearn@USM.

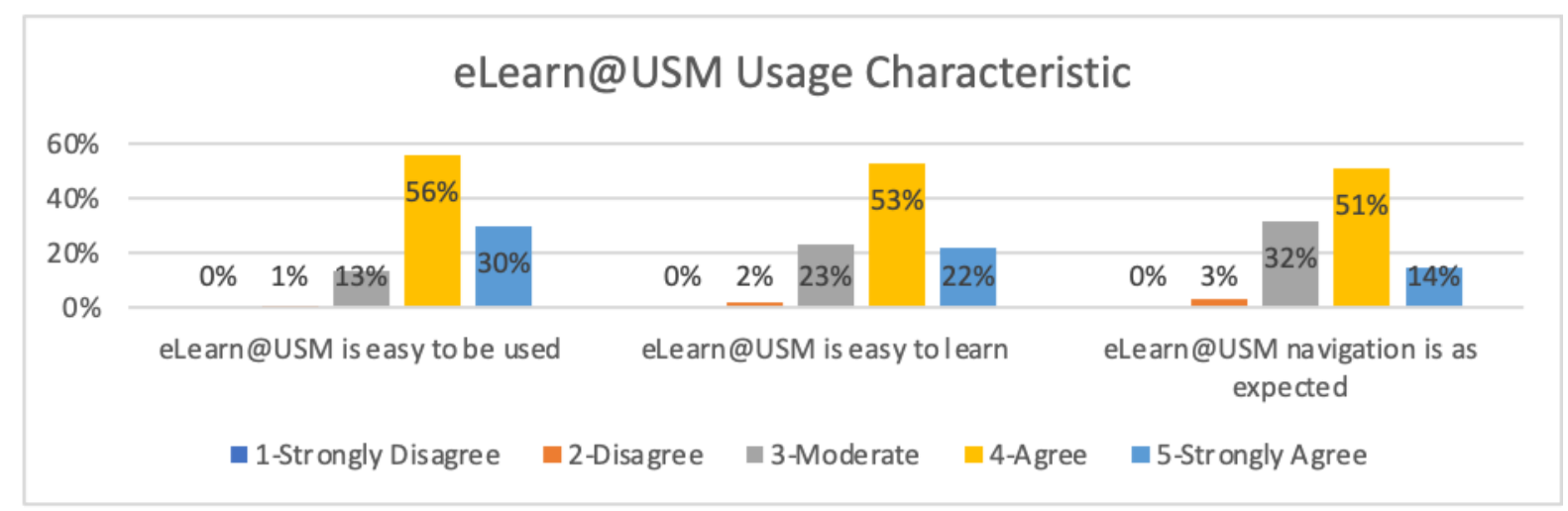

Figure 5: eLearn@USM Usage Characteristic

Figure 5 indicates the percentage of each element in the usage characteristic of eLearn@USM. It can be summarized that the majority of the respondent (above 70\%) agree and strongly agree with the ease of use and user-friendliness of eLearn@USM. However, in 
terms of navigation of eLearn@USM, it is found that only 65\% of respondents agree and strongly agree with it. This percentage indicates that the navigational usage characteristic of eLearn@USM needs to be improved and respondent opinion supported this. Two types of opinions recorded by the respondent. One is on the eLearn@USM itself, where respondents in the opinion that to ease the navigation when using a mobile platform, a mobile-based app should be available. Second is the lecturer uploading material and activity into the eLearn@USM, where the respondent stated that the materials and activity uploaded by some of the lecturers are poorly arranged and sectioned, causing it hard for students to discern which topic the material or activity belongs too.

\section{Overall Satisfaction}

The final section in evaluating user satisfaction towards eLearn@USM is overall satisfaction. The section is the summary of the earlier three (3) sections. It measures the respondent expectations on the eLearn@USM capability to meet the overall teaching and learning process and eLearn@USM usability satisfactory.

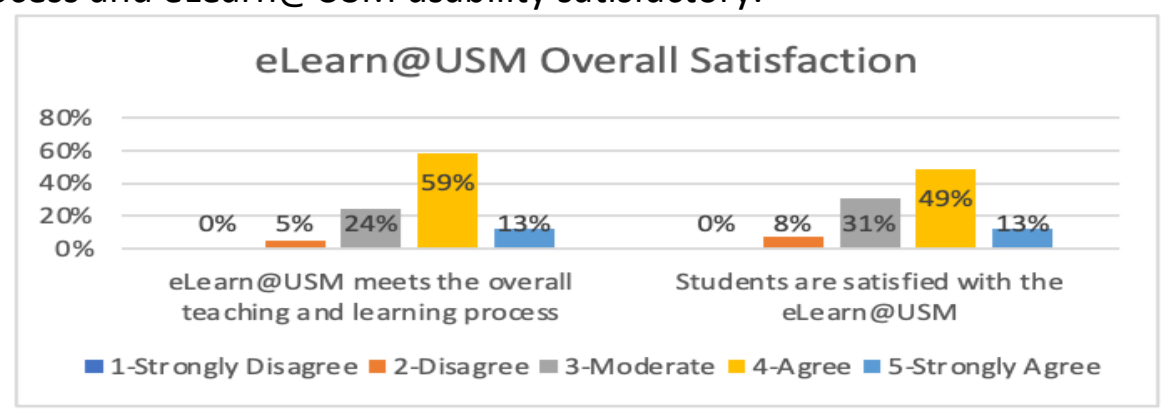

Figure 6: eLearn@USM Overall Satisfaction

Figure 6 indicates the percentage of each element in overall satisfaction towards eLearn@USM. It can be summarized that the majority of the respondent (72\%) agree and strongly agree that the eLearn@USM meets the overall teaching and learning process. However, comparing to the satisfactory of using the eLearn@USM, it is found that only 62\% respondent is satisfied with the eLearn@USM. This is supported by all the opinions mentioned by the respondent in the earlier sections.

\section{Conclusion}

In ensuring the continuity of teaching and learning processes in the education industry, governments, and education providers are moving towards E-learning. Even before the Malaysian government started the Movement Control Order nationwide on 18 March 2020 (Muhyiddin, 2020), USM has proactively started online learning initiatives three (3) days earlier (Faisal Rafiq, 2020). This includes the use of eLearn@USM as the official modes of teaching and learning process. It can be concluded that eLearn@USM is acceptable by the respondent in terms of their information quality, System usefulness, system usage characteristics and overall satisfaction. This was made possible via the proactive efforts by USM top management in planning and mobilization during the COVID-19 Crisis. Furthermore, several improvements were identified namely lecturer capacity and effort in centralizing teaching within eLearn@USM and system improvement for eLearn@USM. In regards to lecturer capacity and effort in centralizing teaching within eLearn@USM, the lecturer should improve the material quality uploaded into the system, ensure that all provided activity has clear instructions, ensure all activity and material are arranged systematically, and to fully 
used eLearn@USM as main teaching and learning platform. In regard to system improvement for eLearn@USM, system providers should have a system notification capability each time new material or activity available to users and to have a simplified app for the mobile user. Considering the current global pandemic (COVID-19) situations, the authors are in the opinion that online learning shall be the immediate solution to the teaching and learning process and considering the proposed improvements, the authors are in the opinion that teaching and learning process through eLearn@USM can be drastically improved.

\section{Acknowledgements}

We would like to thank Universiti Sains Malaysia School of Health science, UiTM Faculty of Electrical for the collaboration in this study. This study is conducted with ethics committee approval (USM/JEPeM/21010100) from the Human Research Ethics Committee of USM and supported by USM grant (304/PPSK/6315498)

\section{References}

Annamalai, C., Koay, S., \& Lee, S. (2014). Role of Social Networking in Disaster Management: An Empirical Analysis. Science Q, 1(3), 1-5. Retrieved from http://scienceq.org/Uploaded/Editorial/1870083851.pdf

Armstrong, B., Fogarty, G., Dingsdag, D., \& Dimbleby, J. (2005). Validation of a Computer User Satisfaction Questionnaire to Measure IS Success in Small Business. Journal of Research and Practice in Information Technology, 37(1), 27-42.

Faisal Rafiq, M. A. (2020). COVID-19: SOCIAL RESPONSIBILITY, PREVENTIVE POLICY AND CURRENT DEVELOPMENTS AT UNIVERSITI SAINS MALAYSIA. Retrieved April 9, 2020, from https://news.usm.my/index.php/english-news/6485-covid-19-socialresponsibility-preventive-policy-and-current-developments-at-universiti-sains-malaysia

Guin, T. D.-L. (2012). Myths and realities of respondent engagement in online surveys. Journal of Market, 54(5), 1-21. https://doi.org/10.2501/IJMR-54-5-000-000

Harian, B. (2020). Kronologi COVID-19 di Malaysia.

Hussin, M. F., Wang, B., \& Hipnie, R. (2012). The reliability and validity of Basic Offshore Safety and Emergency Training knowledge test. Journal of King Saud University - Engineering Sciences, 24(2), 95-105. https://doi.org/10.1016/j.jksues.2011.05.002

Johnston, B. (2015). Confidentiality and qualitative research. International Journal of Palliative Nursing, 21(1), 3. https://doi.org/10.12968/ijpn.2015.21.1.3

Kaiser, K. (2009). Protecting respondent confidentiality in qualitative research. Qualitative Health Research, 19(11), 1632-1641. https://doi.org/10.1177/1049732309350879

Khairilmizal, S., Hussin, M. F. F., Husna, K. A., Yassin, A. I. M., Jusoh, M. H., Sulaiman, A. A., ... Saadun, J. (2017). Criteria for an Integrated Disaster Management System for Lead Responding Agency in Malaysia. Advanced Science Letters, 23(5), 4278-4280. https://doi.org/10.1166/asl.2017.8248

Khairilmizal, S., Hussin, M. F., Yassin, A. I. M., Ainul Husna, K., Jusoh, M. H., Sulaiman, A. A., ... Hussain, A. R. (2017). Design and Development of Strategic Disaster Management Database for Lead Responding Agency in Malaysia during Response and Early Recovery Phases. International Journal of Electrical \& Electronic Systems Research (IEESR), 10.

Khairilmizal, S., Yassin, M. A. I., Husna, A. K., Kasri, M. H., Saadun, J., \& Hussin, M. F. (2019). Evaluation of Lead Responding Agency in Malaysia During Disaster Exercise. In International Conference on Science and Social Research. Pulau Pinang: IPSis UiTM.

Laal, F., Jafari, M., Noorizadeh, N., Fallah Madvari, R., Rahimi, E., \& Ahmadi, E. (2017). Mental 
workload and affecting factors among firefighters in Tehran, Iran, in 2017. Journal of Occupational Health and Epidemiology, 6(4), 184-189.

https://doi.org/10.29252/johe.6.4.184

Leveugle, R., Calvez, A., Maistri, P., \& Vanhauwaert, P. (2009). Statistical fault injection: Quantified error and confidence. 2009 Design, Automation \& Test in Europe Conference \& Exhibition, (APRIL 2009), 502-506. https://doi.org/10.1109/DATE.2009.5090716

Merriam-Webster.com. (2018). Merriam Webster. Retrieved January 11, 2018, from www.merriam-webster.com

MOH. (2020). COVID-19 (Maklumat Terkini). Putrajaya.

Muhyiddin, M. Y. (2020). Prime Minister Speech on 16 March 2020. Prime Minister Office. Putrajaya. Retrieved from https://www.pmo.gov.my/2020/03/perutusan-khas-yabperdana-menteri-mengenai-covid-19-16-mac-2020/

Roosli, R. (2010). Managing disasters in Malaysia: the attitude of officials towards compliance with the MNSC Directive 20. University of Northumbria, Newcastle. Retrieved from http://nrl.northumbria.ac.uk/2925/

Sorensen, C., \& Dahl, C. (2008). Google in the Research and Teaching of Instruction Librarians. Journal of Academic Librarianship, 34(6), 482-488.

https://doi.org/10.1016/j.acalib.2008.09.015

Taskforce USM COVID-19 Pandemic. (2020). Response and Readiness Plan for COVID-19 Pandemic and Other Infectious Diseases Outbreaks. Georgetown. Retrieved from https://www.usm.my/covid19/

Travis, L. (2010). One of Many Free Survey Tools: Google Docs. Journal of Electronic Resources in Medical Libraries, 7(2), 105-114. https://doi.org/10.1080/15424065.2010.482902

USM. (2020). eLearn@USM. Retrieved April 12, 2020, from https://elearning.usm.my/

WHO. (2020). Coronavirus disease (COVID-2019) situation reports. World Health Organization. Geneva. Retrieved from

https://www.who.int/emergencies/diseases/novel-coronavirus-2019/situation-reports 